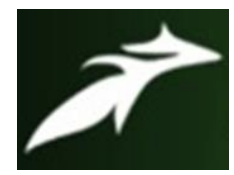

Prashant Verma et al, International Journal of Advances in Agricultural Science and Technology,

Vol.7 Issue.12, December-2020, pg. 59-64

ISSN: 2348-1358

Impact Factor: 6.057

NAAS Rating: 3.77

\title{
Knowledge and Attitude of Cucumber Growers in Janjgir Champa District of Chhattisgarh
}

\author{
Prashant Verma'; Jahanara ${ }^{2}$ \\ 1. M.Sc. Scholar, 2. Prof., \\ Department of Agricultural Extension \& Communication, Sam Higginbottom University of Agricultural \\ Technology \& Sciences, Prayagraj (211007) \\ Corresponding Author e-mail: prashantverma8965820703@gmail.com \\ DOI: 10.47856/ijaast.2020.v07i12.009
}

\begin{abstract}
Cucumber (Cucumis sativas L.) is of the most important vegetable cum salad crops grown throughout the world, belongs to the family Cucurbitaceae. In India the total production of vegetables is 169.1 million metric tonnes in that cucumber has 1,050.10 tonnes hectare (National Horticulture Board). Janjigir District consists of 9 blocks, one block was selected on the basis of highest cultivation area under cucumber, jaijaipur block selected purposively for the present study. 120 cucumber growers were selected from 10 villages using proportionate random sampling method. A well-structured pre tested interview schedule was used for the study. The data was analysed using cumulative frequency method, percentage analysis, correlation. The study revealed that more than half of the farmers (54.16\%) had medium level of knowledge followed by 33. 33 per cent high had high level knowledge. More than half of the farmers (58.33\%) had medium level of Adoption followed by $33.33 \%$ per cent had high level of adoption. Multiple regression revealed that the variables namely Education, land holding, social participation shows positive significance at 0.05 level relate to extent of adoption about cucumber growers. The major production constraints faced by the farmers were low price for tubers due to influctuations in price (93.33\%), shortage of labour (87.5\%), Exploitation of middleman (86.66\%) were the major constraints faced by the cucumber constraints.
\end{abstract}

\section{Introduction}

Cucumber can be grown in field as well as in garden. It is commercially rested for home consumption. Fertile soils are used for the cultivation of cucumber; infertile soils result in bitter and misshapen fruits which are often rejected by consumers. Bush fallowing has been an efficient, balanced and sustainable agricultural system for soil productivity and fertility restoration in the tropics (Ayoola and Adeniran, 2006), but as a result of increase in the population, the fallowing periods have decreased from ten years to three years and this has had an adverse effect on the fertility restoration leading to poor yields of crops. Therefore, the 


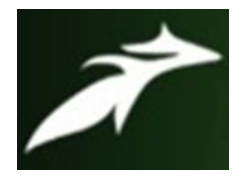

Prashant Verma et al, International Journal of Advances in Agricultural Science and Technology,

Vol.7 Issue.12, December-2020,pg. 59-64

ISSN: 2348-1358

Impact Factor: 6.057

NAAS Rating: 3.77

use of external the form of farmyard manures and fertilizer has become imperative. Farmyard manure has been used as a soil conditioner since ancient times and its benefit have not been fully harnessed due to large quantities required in order to satisfy the nutritional needs of crops (Makinde et al., 2007). The need for renewable forms of energy and reduced cost of fertilizing crops, have revived the use of organic manures worldwide (Ayoola and Adeniran, 2006). Improvement in environmental conditions and public health are important reasons for advocating increased use of organic materials (Ojeniyi, 2000; Maritus and Vleic, 2001). However, because it is bulky, the cost of transportation and handling constitute a constraint to its use by peasant farmers. Cucumber is a trailing annual crop which bears elongated fruits mainly used as a salad and is only of recent introduction in parts of Andhra Pradesh, although it is very popular in North India and even in the neighbouring states of Karnataka. The crop is cultivated in an area of 41,000 hectares in India with the total estimated production of 6.10 lakh MT(NHB, 2012-13) The seed of cucumber is highly nutritive due to there high oil and protein content seed protein of cucumber is comparable in nutritive value to those of legumes. Mathonine content is more in cucumber as compared to legumes. Timber is used as salad, as a pickle too. Cucumber is having 83 percent edible portion, water content is 96.3 percent, protein is 0.40 percent, mineral are 0.30 percent, carbohydrates 2.5 percent while energy is $13 \mathrm{k} \mathrm{cl} / 100 \mathrm{gm}$. It also content 10.00 percent calcium $0.03 \mathrm{mg}$ thiamine, $0.04 \mathrm{mg}$ riboflavin. Cucumber is chief source of vitamin, mineral and carbohydrates.

\section{METHODOLOGY}

This study was conducted in Janjgir Champa district of Chhattishgarh, by purposive sampling Cucumber is grown in more than 5 thousand hectare area in the district. The district contributes more than 1.5 per cent and 2 per cent of total area and production of total Cucumber in the state. The farmers of Jaijaipur Block were interviewed. The total sample size for this study was 120 farmers. Data collected were tabulated on the basis of logical categorization method for calculation of Percentage, Frequency analysis purposes. The following formula was used to ascertain the technological gap in adoption of each of the considered practices. 


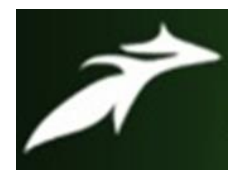

Prashant Verma et al, International Journal of Advances in Agricultural Science and Technology,

Vol.7 Issue.12, December-2020, pg. 59-64

ISSN: 2348-1358

Impact Factor: 6.057

NAAS Rating: 3.77

\section{RESULTS AND DISCUSSION}

Knowledge level: The data in Table 1 shows that the farmers do not have adequate knowledge about $\mathrm{pH}$ of soil, recommended doses of fertilizer and control of whithfly.

The data presented in table 2 reveals that majority

71.66 per cent of the cucumber growers were having medium level of knowledge, followed by 5.83 per cent of growers, who had low level of knowledge and 22.50 per cent of growers were having the high level of knowledge regarding cucumber cultivation.

Table:1. Distribution of respondents based on their Level of Knowledge on Cucumber improved production practices

\begin{tabular}{|l|l|l|l|l|}
\hline \multirow{2}{*}{ S.NO } & \multirow{2}{*}{ Statements } & \multicolumn{3}{c|}{ Knowledge Level } \\
\cline { 3 - 5 } & & \multicolumn{1}{|c|}{ Fully } & \multicolumn{1}{c|}{ Partially } & \multicolumn{1}{c|}{ No } \\
\hline 1 & Recommended Cucumber Variety & $88(73.33)$ & $30(25.00)$ & $2(1.66)$ \\
\hline 2 & Suitable Soil & $111(92.50)$ & $8(66.66)$ & $1(0.83)$ \\
\hline 3 & Seed rate & $81(67.50)$ & $37(30.83$ & $2(1.66)$ \\
\hline 4 & Seed are planted & $119(99.16)$ & $1(0.83)$ & $0(0.00)$ \\
\hline 5 & Nodes present in setts & $116(96.66)$ & $4(3.33)$ & $0(0.00)$ \\
\hline 6 & Length and depth of sowing & $90(75.00)$ & $28(23.33)$ & $2(1.66)$ \\
\hline 7 & FYM requirement & $52(43.33)$ & $61(50.83)$ & $7(5.83)$ \\
\hline 8 & Spacing & $114(95.00)$ & $6(5.00)$ & $0(0.00)$ \\
\hline 9 & Dipping solution & $41(34.16)$ & $68(56.66)$ & $11(9.16)$ \\
\hline 10 & Important pest \& Diseases & $90(75.00)$ & $28(23.33)$ & $2(1.66)$ \\
\hline 11 & Recommended Fertilizers & $1(0.83)$ & $28(23.33)$ & $91(75.83)$ \\
\hline & pH of soil & $2(1.66)$ & $4(3.33)$ & $114(95.00)$ \\
\hline
\end{tabular}




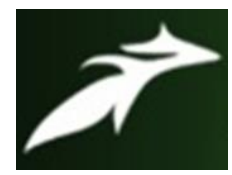

Prashant Verma et al, International Journal of Advances in Agricultural Science and Technology, Vol.7 Issue.12, December-2020, pg. 59-64

ISSN: 2348-1358

Impact Factor: 6.057

NAAS Rating: 3.77

\begin{tabular}{|l|l|l|l|l|}
\hline 13 & Control of whitefly & $7(5.83)$ & $55(45.83)$ & $58(48.33)$ \\
\hline 14 & Growing intercrop & $116(96.66)$ & $2(1.66)$ & $2(1.66)$ \\
\hline 15 & Duration & $120(0.00)$ & $0(0.00)$ & $0(0.00)$ \\
\hline 16 & Tubers can be uprooted by & $85(70.83)$ & $35(29.16)$ & $0(0.00)$ \\
\hline 17 & Yield & $113(94.16)$ & $7(5.83)$ & $0(0.00)$ \\
\hline 18 & Post harvest management & $120(0.00)$ & $0(0.00)$ & $0(0.00)$ \\
\hline 19 & Value added product & $120(0.00)$ & $0(0.00)$ & $0(0.00)$ \\
\hline
\end{tabular}

Table: 2 .

\begin{tabular}{|l|l|l|l|}
\hline $\begin{array}{l}\text { S. } \\
\text { No. }\end{array}$ & Level of knowledge & Frequency & Percentage \\
\hline 1. & Low (19-31) & 7 & 5.83 \\
\hline 2. & Medium (32- 44) & 86 & 71.66 \\
\hline 3. & High (45-57) & 27 & 22.50 \\
\hline \multicolumn{2}{|c|}{ Total } & 120 & 100 \\
\hline
\end{tabular}

The: table 3. shows that maximum attitude level among the respondents was in Additional labour generated through improved production practices 45.83 per cent followed by 38.33 per cent I think that cucumber cultivation is suitable only for those farmers who have irrigation facility. 


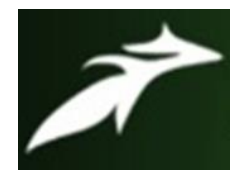

Prashant Verma et al, International Journal of Advances in Agricultural Science and Technology,

Vol.7 Issue.12, December-2020, pg. 59-64

ISSN: 2348-1358

Impact Factor: $\mathbf{6 . 0 5 7}$

NAAS Rating: 3.77

Table: 3. Distribution of respondents based on their Attitude towards Cucumber improved production practices

\begin{tabular}{|c|c|c|c|c|c|c|c|c|c|c|c|}
\hline \multirow{3}{*}{ S.No } & \multirow{3}{*}{ Statements } & \multicolumn{10}{|c|}{ Attitude Level } \\
\hline & & \multicolumn{2}{|c|}{ SA } & \multicolumn{2}{|l|}{$\mathrm{A}$} & \multicolumn{2}{|c|}{ UD } & \multicolumn{2}{|c|}{$\mathrm{DA}$} & \multicolumn{2}{|c|}{ SDA } \\
\hline & & $\mathrm{F}$ & $\mathrm{P}$ & $\mathrm{F}$ & $\mathrm{P}$ & $\mathrm{F}$ & $\mathrm{P}$ & $\mathrm{F}$ & $\mathrm{P}$ & F & $\mathrm{P}$ \\
\hline 1 & $\begin{array}{l}\text { Additional labours generated } \\
\text { through improved production } \\
\text { practices }\end{array}$ & 55 & 45.83 & 51 & 42.5 & 7 & 5.83 & 5 & 4.16 & 2 & 1.66 \\
\hline 2 & $\begin{array}{l}\text { I prefer to adopt improved } \\
\text { production practices in } \\
\text { cucumber crop because of } \\
\text { getting higher yield }\end{array}$ & 12 & 10.00 & 43 & 35.83 & 43 & 35.43 & 14 & 11.66 & 8 & 6.66 \\
\hline 3 & $\begin{array}{l}\text { Storage facility does not } \\
\text { helps in distribution of } \\
\text { cucumber }\end{array}$ & 13 & 10.83 & 62 & 51.66 & 23 & 19.16 & 20 & 16.66 & 2 & 1.66 \\
\hline 4 & $\begin{array}{l}\text { Middleman does not perform } \\
\text { malpractices during } \\
\text { marketing of cucumber }\end{array}$ & 5 & 4.16 & 3 & 2.5 & 12 & 10 & 42 & 35 & 58 & 48.33 \\
\hline 5 & $\begin{array}{l}\text { Improved } \\
\text { production } \\
\text { designed and developed } \\
\text { based on the needs of the } \\
\text { people }\end{array}$ & 1 & 0.83 & 3 & 2.5 & 81 & 67.5 & 27 & 22.5 & 8 & 6.66 \\
\hline 6 & $\begin{array}{l}\text { I need financial assistance to } \\
\text { adopt improved production } \\
\text { practices in cucumber }\end{array}$ & 1 & 0.83 & 34 & 28.33 & 56 & 46.66 & 28 & 23.33 & 1 & 0.83 \\
\hline 7 & $\begin{array}{l}\text { I think that cucumber } \\
\text { cultivation is suitable only } \\
\text { for those farmers who have } \\
\text { irrigation facility }\end{array}$ & 46 & 38.33 & 72 & 60.00 & 2 & 1.66 & 0 & 0.00 & 0 & 0.00 \\
\hline 8 & $\begin{array}{l}\text { Cultivation of high yielding } \\
\text { modern varieties is not } \\
\text { always helpful to improve } \\
\text { the economic condition of } \\
\text { the farmers }\end{array}$ & 2 & 1.66 & 8 & 6.66 & 76 & 63.33 & 30 & 25 & 4 & 3.33 \\
\hline
\end{tabular}




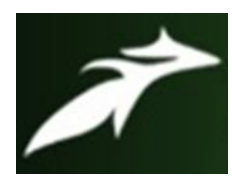

Prashant Verma et al, International Journal of Advances in Agricultural Science and Technology,

Vol.7 Issue.12, December-2020, pg. 59-64

ISSN: 2348-1358

Impact Factor: 6.057

NAAS Rating: 3.77

Table 4.

\begin{tabular}{|l|l|l|l|}
\hline S.No. & Attitude level & Frequency & Percentage \\
\hline 1. & Low (8-13) & 15 & 12.5 \\
\hline 2. & Medium ( 14- 19) & 65 & 54.16 \\
\hline 3. & High ( 20 - 24) & 40 & 33.33 \\
\hline Total & 120 & 100 \\
\hline
\end{tabular}

The table: 4. Indicate the majority of the respondents (54.16\%) had medium level of overall attitude. There were 12.5 per cent and 33.33 per cent respondents who had low and high level of attitude towards cucumber cultivation practices

\section{CONCLUSION}

In the light of said finding and discussion of the present study, the following conclusion can be draw. The majority of the cucumber grower 71.66 per cent have medium knowledge level followed by 5.83 per cent belonged to low knowledge level and 22.50 per cent falls in high knowledge level.

The study demands the effective extension efforts (training, field demonstration, more interaction with the farmers) to be made to transfer the knowledge among the growers so that the knowledge level can be increased which in term will helps in the developing positive attitude towards cucumber cultivation and more profit to the cucumber growers.

\section{REFERENCES}

[1]. HinaSaeed, AnamWaheed (2017) A Review On Cucumber International Journal of Technical Research \& Science Volume 2 Issue VI.

[2]. N.S.Gill and M.Bali (2011). Isolation of antiulcer Cucurbitane type triterpenoid from the seeds of Cucurbitapepo. Research Journal of Phytochemistry: Vol. 5 (2) 70-79.

[3]. E. K. Eifediyi, and S. U. Remison, (2010). Growth and yield of cucumber (Cucumissativum L.) as influenced by farm yard manure and inorganic fertilizer. J. Plant Breeding and Crop Sci. 2(7): 216-220.

[4]. LU. Okonmah.( 2011) Effects of different types of staking and their cost effectiveness on the growth, yield and yield components of cucumber (Cumumissativa L). Int. J. of Agric. Sci.1(5): 290295,.International Academic Journals, Germany.

[5]. Adetula O, Denton L (2003). Performance of vegetative and yield accessions of cucumber (CucumissativaL.) Horticultural Society of Nigeria (HORTSON) Proceedings of 21st annual conference 10-13 Nov.

[6]. K.Patil., A Kandhare., D Bhise. (2012.) Effect of aqueous extract of Cucumissativus Linn. fruit in ulcerative colitis in laboratory animals. Asian Pacific Journal of Tropical Biomedicine: 962-969. 